\title{
Opera glass hands: the phenotype of arthritis mutilans
}

\author{
Maria Betânia Ferreira, Nuno Sá, Sara M Rocha, António Marinho
}

Department of Internal Medicine, Centro Hospitalar Porto, Porto, Portugal

\section{Correspondence to}

Dr Maria Betânia Ferreira, betania_ferreira82@hotmail.com
To cite: Ferreira MB, Sá $N$, Rocha SM, et al. BMJ Case Rep Published online:

[please include Day Month

Year] doi:10.1136/bcr-2013200035

\section{DESCRIPTION}

A 51-year-old man was diagnosed with psoriatic arthritis at the age of 18 .

For the last 20 years he refused treatment, abandoned any follow-up and was unseen by any health professional. The patient became unable to walk 17 years ago and then went blind 10 years ago.

The patient entered the emergency room prostrated; on examination, he was found cachetic in appearance, with psoriatic skin eruptions and nail

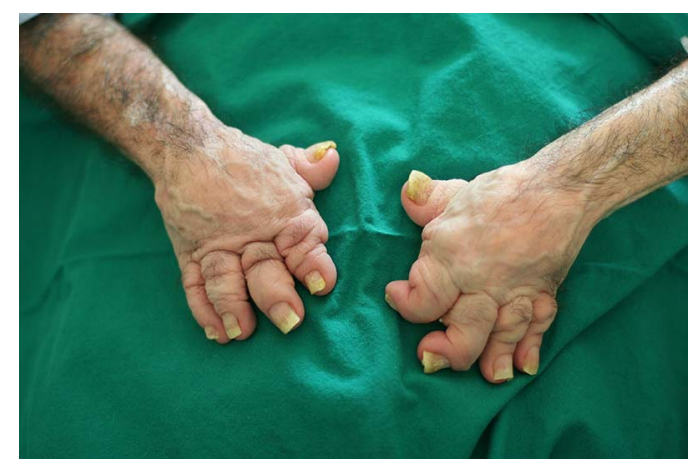

Figure 1 Patient's hands: shows redundant skin over shortened fingers and onycholysis and nail pitting is visible.

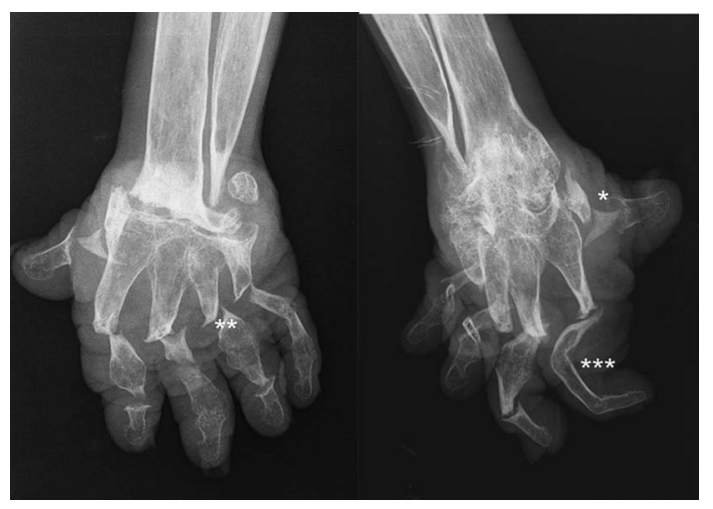

Figure 2 Hands X-ray, depicting the major phases of evolution in psoriatic arthritis: pencil in cup images $\left({ }^{*}\right)$; resorption of bone and dissolution of joints $\left({ }^{* *}\right)$; fusion of fingers $\left({ }^{* *}\right)$. changes, axial anquilosis and hands with 'telescopic fingers' (figures 1 and 2)

Arthritis mutilans is the most severe and destructive form of psoriatic arthritis, range from $3.7 \%$ to $6.7 \%$ according to different studies. ${ }^{1}$ When Digit's articular collapse, it leaves redundant overlying skin in shorter fingers, able of a motion like a telescope-the telescopic finger.

Today, with early diagnosis and easy access to disease modifying antirheumatic drugs, such severe deformities are extremely rare. ${ }^{2}$

\section{Learning points}

- Arthritis mutilans (AM) has been described in association with a wide variety of arthropathies, including rheumatoid arthritis, psoriatic arthritis, juvenile idiopathic arthritis, systemic sclerosis, Systemic lupus erythematosus and others, being the first two most commonly associated diseases. ${ }^{12}$

- AM is characterised by an asymmetric pattern of peripheral joint involvement, with a predilection for the interphalangeal and metacarpophalangeal joints of the hand and small jointes of the feet. ${ }^{1}$

- Radiographically, AM is characterised by the presence of severe boné and joint resorption and deformities.

\section{Competing interests None.}

Patient consent Obtained.

Provenance and peer review Not commissioned; externally peer reviewed.

\section{REFERENCES}

1 Rodrigues- Moreno J, Bonet M, Blanco-Barnusell J, et al. Mutilating/resorptive arthritis. A study of 24 patients in a series of 360 patients with psoriatic arthritis. Reumato/ Clinic 2013;9:38-41.

2 Pomerantz RG, Mody E, Husni ME, et al. Follow-up of psoriatic arthritis mutilans patients treated with anti-TNF alfa therapy. J Drugs Dermatol 2009;8:406-12.

Copyright 2013 BMJ Publishing Group. All rights reserved. For permission to reuse any of this content visit http://group.bmj.com/group/rights-licensing/permissions.

BMJ Case Report Fellows may re-use this article for personal use and teaching without any further permission.

Become a Fellow of BMJ Case Reports today and you can:

- Submit as many cases as you like

- Enjoy fast sympathetic peer review and rapid publication of accepted articles

- Access all the published articles

- Re-use any of the published material for personal use and teaching without further permission

For information on Institutional Fellowships contact consortiasales@bmjgroup.com

Visit casereports.bmj.com for more articles like this and to become a Fellow 